\title{
「語り得ないもの」を語ること \\ 一アイヌ・ル・クダート・ハマダーニーの例を通じて一一
}

\section{How to Tell About Something Impossible to Tell: the Example of 'Ayn al-Quḍāt Hamadhānī}

\author{
山 崎 光 子 \\ YAMAZAKI Mitsuko
}

\begin{abstract}
Mystics often express in their writings how difficult, rather how almost impossible it is to tell what they want to tell based upon their own mystical experiences. However, many of them dare to try. Thus some questions can be asked, such as why they have to tell or how they tell.
\end{abstract}

'Ayn al-Quḍā t Hamadhānī (d. 525/1131) is one such mystic. In his work Zubdat alHaqā'iq, Hamadhānī not only confess that impossibility, but also consciously analyzes from a linguistic point of view why it seems impossible. His aim is tell about the events of the above-reason region, or the region of wisdom, since he is earnest about leading reasoning people from the region of reason to the above-reason region. However, such a transcendental region is beyond language delimitation. It is impossible to express it as it is by normal language. Therefore, he is forced to write using a special method of expression, namely "metaphorical expressions (tashābuh, mutashābih etc.)". He says that he needed much effort to make his language express the true state of affairs within the above-reason region as accurately as possible, even if it could never transmit the real facts of that region.

As some features of this method of expression, I will give three examples. The first type is applying one term to what are, in a true sense, different meanings between the two regions. The second is applying schemes of the events within the region of reason to those within the region of wisdom, the third is through apophatic wording and contradictory statements, proving the region of wisdom transcends the bounds of the region of reason. Sometimes using philosophical or theological terms and notions, Hamadhānī seems to pursue the possibility of linguistic expression through them.

These "metaphorical expressions" are an incentive for the reasoning person to attain the above-reason region. However, these are only clnes on how to do so. Hamadhāni gives his readers repeated warnings not to stay within the range of "metaphorical expressions", and recommends them to come to believe in the above-

* 本学会正会員

Member, Society for Near Eastern Studies in Japan 
reason region blindly. This belief is the final condition for attainment of the region.

Consequently, I would like to say it is worthwhile to grasp how to comprehend mystical texts, for we can get hints here to help us decide how we should face the texts and finally head for the reality the existence of which the texts suggest.

\section{I. はじめに}

神秘主義のテキストは，しばしば言語として語ることの困難さや不可能性を記述のうち に表明する。意識の変容を伴う体験が神秘主義において要請される以上, 書き表わすのが 困難であろうことは想像に難くない。それでも多くの神秘家たちが自らの体験に基づい てテキストを書き残してきた。それは，彼らが何かを伝える必要性を感じ，何かを伝え 得ると考えたからであろう。

本来語り得ないものを敢えて語るならば，なぜ語らねばならないか，どのように語っ ているかということが問題として浮かび上がってくる。それらを知ることによって，テ キストの内容を把握するための方向性を見い出し得ると考えるからである。本稿では, アイヌ・ル・クダート・ハマダーニー ('Ayn al-Quḍāt Hamadhānī 525/1131 年没。以

下，ハマダーニー）のテキストを通じて，そうした語りに対する神秘家の意識のあり方 について一つの例を提示し，その意味するところを考えたい。

ハマダーニーは, 12世紀前半に活躍したイランの神秘家で, 1098年にハマダーンに生ま れた。早熟で10代の内にあらゆる学問を修めるが，理性的な知による学問に疑問を抱き， アブー・ハーミド・アル・ガザーリーの諸著を学ぶことによって, 迷いから脱する手立 てを得る。その後, アブー・ハーミドの弟，アフマドの教示により本格的に「神への道」 に入った。1122年には哲学的・思弁的と評される Zubdat al-Haqā’iq を著し（以下， $Z u b d a h)$, 翌年から1131年にかけて, 多くの書簡 (Maktūbāt) を残した。1127年には文学 的・詩的といわれるTamhīdat も著述している。しかし，後に異端の廉で告発を受け， Shakwā'al-gharīb (1131年) という弁明書によって抗弁するも叶わず，1131年に処刑され 短い生涯を終えた。上記の著作のうち, Zubdah と Shakwā' al-ghañb はアラビア語, Maktūbāt と Tamhīdāt はペルシア語で書かれている。

本稿では Zubdah を扱う。ハマダーニーはZubdahにおいてテキストの言表不可能性 を明示しているが，なぜ語るのが困難であり，それにも関わらずなぜ語るのか，語るの ならどのように語るのかということに対しても意識的に述べているところが興味深い。 ここでは，八マダーニーの言語観に触れつつ，語りの難しさの所以と敢えて語る理由を 明らかにした上で，ハマダーニーが語るために用いている「比喻的表現（tashābuh， mutashābih など)」について具体例を挙げて分析する。 


\section{II. 表現不可能性と敢えて語ること}

ハマダーニーは冒頭で, Zubdahにおける叙述内容を「解勫を施し, 描写するのが私(ハ マダーニー)にとって困難であるような, 不可視的な諸々の耪智 (al-ma‘ārif al-ghaibìya) や（神秘を）開示するような諸状態という宝石（nafā’is al-ahwāl al-kashfīyah）であ ク」，それらは「文字と音によって語る者たちの世界で表現するのは不可能なことに属す (9)

るもの」と表明する。

しかし，彼は敢えて語るのであり，語るために「私は以下の諸節で，それらのことが ら（先の引用に見える畋智などを指す）を最もふさわしく示唆（ahsan ishārah）し，最 も鋭い表現 (arshaq ‘ibārah) を以て述べるように極限までの努力を重ねた」のだある。 少々先取りすれば，そこで彼の用いようとするのが「比喻的表現」である。「この著作に おける，上述したような言葉の多くは，比喻的に表現し得る限りでの「比喻的表現」 (mutashābihah ghāyat al-tashābuh) だというのが至当である。」

ハマダーニーは，言語には文字としての表記（'ibārah, lafẓ など）と，それによって指 し示されるところの意味あるいは内容 (ma'nā) とがあると考える。そして, Zubdahに おいては扱う内容とその表記が一致し得ないところにテキストの内容を語ることが困難 である原因があると見ている。Zubdah中の言葉とは「どれほどそれらの表記について考 えを巡らせても，表記という型にはめこまれていて真の意味内容は伝わらない」ような 言葉なのである。

ハマダーニーはその理由を，この著作の目的が「理性的な知よりも高貴な (ashraf min al-'ulūm al-'aqliyah) ことがらを説くこと」であるからだとしている。すなわち, Zubdah の内容は, 理性を超えた領域（țawr warā’ al-‘aql 以下，超理性域）あるいは䍊智 （ma'rifah）の領域，現象的世界を超越した神的世界に属するのである。

しかるに，言語はもとより諸々の存在物を言い表わすためにあるものであり，本来的 に現象界に属しているといえる。従って言語を神的領域に対して適用するとき必然的に 歪みが生じてくる。例えば「親しみ（uns）」という概念について，通常は思弁的な知 (al-‘ulūm al-nazarīyah) に対する「親しみ」を意味するが, 神的領域において「親しみ」 とは神の顕現を直に観照することへの「親しみ」を指す。“uns”という表記は共通してい ても内容は異なるということである。ところが, 理性の領域にある者は神的領域におけ る「親しみ」に対しても, 思弁的な知に対する「親しみ」を想起してしまうものなので ある。むろん, それは大いなる誤りで, 神的領域への「親しみ」は現象界における「親 しみ」という概念の表記を借用しているに過ぎない。

同様に，「能力 (qudrah)」とは，神が人間の内部に創った，それによって人間が何か を為すことを可能とするものであり，それを被造物である人間の術語 (ișțilāḥ) によって 
名付けたものである。しかしまた同時に, 非存在に存在を与える神の作用に対してもこ の表記が適用される。すなわち，言語は現象界の内部で用いられる道具であり，呫智に よって直観的に捉えられるような神的領域のことがらを表現するには不十分なのだとい える。「言語表現の背後には驚嘆すべき秘密 ('ajā'ib al-asrār)」の世界が広がっているの である。

このように，語るべき内容が言語によって表現できる次元にない以上, Zubdahを語る のは本来的には不可能ということになる。それでも語らねばならないのは,ハマダーニー には語ってやりたい相手がいるからだ。思弁的な知を追求するも飽き足らず，理性の次 元の彼方を求めてやまない人々（以下，理性者）のために Zubdah は著されたのであ る。彼らは目下，理性の領域にいる。ところが，理性では䧻智の領域について真には理 解できない。現象界を超えたことがらを「真に認識するには超理性域に拠らねばな らず， ․理性がそれらの表記によって認識する意味は，ことがらの真の意味から程遠 い。」㪍智の領域は, やはり最終的には探求者自らの体験によってのみ感得せられる次元 である。しかし，そこまで到り着かない者たちにその内容を伝えるには，差し当たって 言語表現を手段として用いるほかはない。だからこそハマダーニーは敢えて語り出す。 だが，いざ表現してみるとやはり㕡智的領域は言語表現を超越しており，捉えきれない という次第なのである。

語り得ないものを語る困難さという問題に戻れば，ハマダーニーが Zubdah を記述す るに当たっては, 本来的に言語では表現し尽くせない内容を, 直接には理解できない人々 に対して言語を用いて伝えざるを得ないという二重の制約が課されていることになる。 そのとき，「そのような（理性を超えた）内容を，それらに合致する表記を以て言及する のに，「比喻的表現」を用いずにすることはほとんど不可能である。否，（不可能である のは）絶対確実である。」かくて,「比喻的表現」と訳してきた表現方法の使用が不可避 であるとの表明がなされる。以下，この表現方法について検討する。

\section{III. 比喻的表現の分析}

比喩的表現については，質的なあり方を確認し

た上で具体的な使用例の分析を通じて，事物のどのような類似性に着目した使い方なの かを見る。最後にこの表現を用いての著者の狙うところを考察する。

先述のように, Zubdahにおける大半の言葉は「比喻的表現」であるとされている。従つ て最も広い意味での「比喻的表現」とは，本来言語では表現しきれないことがらを，可 能な限り真の内容に近づけようとする表現方法と考えられる。すなわち, 現象界という 下位の領域に属する言語を上位の神的領域に対して適用するというのが「比喻的表現」 
の方法だといえる。

従って,「比喻的」に表現された表記そのものは現象界の範疇に留まるのであり，それ 自体として理解している限りにおいて, 真の意味内容を把握することはできない。「比喻 的表現」はただ，神的領域へ達するための手掛かりとなり得るところに意味があるので あって，決してそれ自体を目的とみなしてはならないのである。

但し, 異なる認識能力を持つ複数の主体が想定されている場合, ある一つの表記は各

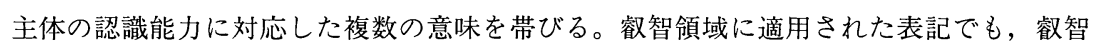
者によって把握される限りにおいて㕡智超域相応の内容を意味し得るということである。 このような場合, 感覚や理性による言語理解にも同様に一定の意味が認められる。

例えば「近さ (qurb)」「遠さ (bu'd)」という概念は, 感覚レベルでは空間的・時間的 観点から, 理性レベルでは理性的能力の観点から捉えられる限りにおいては妥当 (sahīh) である。前者について，「月は太陽よりも（空間的に）我々に近い。」あるいは「ムハン マドの時代はアダムの時代より（時間的に）我々に近い。」と言うことができ, 後者につ いては「シャーフィーはアブー・ジャフルより（理性的能力において）アブー・バクル に近い。たとえ，アブー・ジャフルがシャーフィーよりもアブー・バクルに時間・空間 的に近いとしても。」ということになる。このように, 属する次元の異なる認識主体を設 定するとき, “tashābuh”, “mutashābih”などの術語は一つの言葉の意味が諸次元に跨が る事態となり，「垂直的多義性」を意味するといえる。

以上から, “tashābuh”, “mutashābih”などは, そのものとしては下位次元から上位次 元へと言語を適用する「比喻的表現」として, 能力の異なる複数の主体によって認識さ れるという観点からは「多義的表現」として考えられる。しかし, Zubdah は基本的に理 性者を導くために書かれているため,「比喻的」な用法の方が強く意識されている。従っ て，具体的に分析するのは「比喩的表現」と訳されるような表現のあり方とする。

以上のように，「比喻的表現」の一般的性格を規定した上で, 実際の使用例を見ていく と言語の適用の仕方に複数あるのが認められる。現象界と神的領域とでは意味内容が異 なる別々の事態に対して同じ表記を適用する方法, 現象界内のある事象の構造を神的領 域に対して適用する方法，既存概念を否定する，あるいは矛盾，対立する表現を統合的 に捉えることによって神的領域の現象界に対する超越性を表そうとする方法などが挙げ られる。

第一に，異なる事態に対して共通の表記を当てるという場合だが，先の「親しみ」の 例がこれに相当する。別の例として「知 ('ilm)」を取り上げよう。「知」とは神の属性で あるため, 本来神に対して用いるべきであって, 神以外のものに適用する方が比喻 (majāz) 的, 非本来的な用法なのである。しかし, 理性者にとっての「知」とは諸存在 
物に関する（理性による）「獲得知（al-'ilm al-mustafād）」を意味し，このような「知」 を理性者は比喻的に (bi-țarīq al-tashābuh) 神にも適用してしまうう。その結果, 神の「知」 も現象界の事物に拠っていると考え, 諸事物の変化は神の「知」をも変化させることに なるため，神は個物を知らないと結論付けるという誝りを犯すことになる。しかし真実 は, むしろ個物の方がその存在を神に拠っているのであり, 神の「知」はあらゆる存在 物を包摂 (muhịt) しているのだから, 個物の変化によって影響されはしない。すなわち, 神の「知」は現象界の枠組を超越している。

理性者としては神の「知」であっても理性的な「知」によって表現するしか方法はな い。だがその際には，理性的次元に捉われて以上のような誤りに陥らないよう常に注意 しなければならないのである。

第二は, 存在物の構造を神的領域に適用するという方法である。「能力 (qudrah)」を 例に挙げよう。「能力」とは, 先述したように神が人間の内部に創ったある性質で, 例え ば人間がいつでも望むときに発語できるという場合の「発語できること」を指す。この 例では,「能力」が原因 (sabab) に, 言葉 (kalām) が結果 (musabbab) に相当するが, 原因のみでは結果は潜在的状態にあり，条件（shart）たる意志（mashỉah）が存在する (39)

ことで現実化する。原因が存在するのに結果が不在という事態が生じているが，これは 原因に欠陥（khalal）があるからではなく，単に条件の欠如しているためであるとされ (40) る。

以上のような, 原因に対する条件の発動によってはじめて結果が存在するという構造 が神にも適用されるのである。神の「永遠なる能力」(al-qudrah al-azaliyah) は, 非存 在の状態にある事物に存在を与えるという意味で原因である。結果は事物の存在という ことになるが, 存在物は神があれば即ちある, というわけではない。時間の中で生起し てくるものだ。ここでやはり「条件」が必要となる。「条件」が存在するようになると, 神が対象物を必然的に存在させるというのである。この場合も, 神が端的に存在してい るのにある事物が存在していないのは, 単に「条件」が欠けているのみで, 神の完全性 は何ら損なわれない。太陽の光が雲に遮られて地上に届かないとき，太陽の側に何の欠 陥もなく，雲が太陽自体に影響を及ぼしているわけではないのと同じなのだ。

神的次元でいう「条件」が具体的に如何なるものなのかについては, 明言がない。「永 遠なる能力」という原因を補完する機能を持つかのように見えるが，八マダーニーはこ れを否定する。雲の消散は非存在的なことがら（amr 'adamī) なので，何かを存在させ る作用を持つべき原因性 (sababiyah) としてふさわしくないとするのである。そして八 マダーニーはこの記述以上の比喻的な（tamthi1）説明は無理だとし, 記述を止めてしま うため,「条件」の存在論的な位置付けは明確にならない。 
また，以上の例は同じ表記で異なる内容を示すタイプの表現方法ともなっているため， そちらの面も確認する。「能力」が何かを造り出す力であるという点は両者に共通してい るが, 神と人間ではその力の及ぶ範囲が異なる。神の「永遠なる能力」は無 (1ā min shay') から存在物を創造できるのに対し，人間の「能力」ではそれができないということだ。 換言すれば，人間の「能力」は表面的な原因（al-sabab al-ẓāhir）でしかなく，一般的な 人間には何かを造り出せるかのように見えるだけで, 真に原因にふさわしいのは神の「能 力」のみである。

もう一つ，事物の構造適用の例として鏡に関する比喻が挙げられる。鏡と何かしら物 体があるとしよう。鏡にはその物体の像が映る。この場合，「鏡の中の像は本来的には一 時的な儚い (fāniyah) ものであり，外在する物体によらずしては存続 (baqā') できな (48) い。映像は本性的な存在者ではなく, 存在として独立していない。それはむしろ, 鏡・ 外在する物・（前二者との間に生じる）関係・見る者の凝視という四つの事象から成り 立っている

理性者は，鏡から以上のことを理解し，考察を深めていくと，「彼（神）の御顔の外す べてのものは消滅する」という神の言葉を明証的に真実として理解できるというう。現象 界及び神的領域の神に対する関係は，鏡に映る像の外在物に対する関係と等しいことに 気付き, 現象界にも神的領域にも真の存在性はなく, 両者の存在は真の存在者たる神の 存在に拠っていると知ることができるのである。

鏡に映る像と外在物とがなす関係は，存在物一般と神との間に成り立つ関係に構造的 に類似しているといえる。もちろん, 鏡に関する表現は一般人にわかりやすい感覚的な 比喻によるもので，䠝智者からすれば，鏡の外にある事物にしたところがやはり一時的 なものに過ぎず，それは鏡の中の像が消えゆくものであるのと何ら変わるところはな (54) そして，このことが比喻的な表現とされる所以である。

また, 鏡と外在物の間の関係が無に帰してしまうと, 像の存在も失われてしまうのと 同様に，現世の存在物を真の存在物と思い込んでいるような者たちにとって，彼らの眼 と感覚の対象物との間の関係が失効すれば目から覆いがはずれて「彼（神）の御顔の外 すべてのものは消滅する」事態を確信できるとされる。

さらに，外在物の形や鏡との関係が変化した場合にも言及があり，その変化と同様の 仕方で映像が変化するため, 外在者の存在は映像に対し時間的にではなく位階的 (rutbiy) に先行していることが明瞭になるといゔ。このケースは神と存在物との関係に 対する適用例がないのだが，上述の内容からすれば神が存在者に対して時間的に先行し ているのではなく, 位相的に先行しているという構造を比喻的に示していると推測され よう。 
第三に，既存の概念を否定的に用いる，または矛盾する表現を統合しようとする表現 について，ここでは時間概念を用いた表現を取り上げて論じたい。過去から現在そして 未来へと不可逆的に流れていき，決して複数の時点が同時に成立することがないという 時間の性質に, 神が捕われることはない。神にとっては時間軸上のいずれの点も同一で あり，あらゆる時間は同時に成り立つのである。

例えば以下のように言われる。「時間的過去 (al-māḍī) ・ 現在 (al-hāạdir) ・ 未来 (almustaqbal) の神に対する関係はいずれも等し(58) あるいは,「神の未来という時間に対 する先行性（sabq）と過去に対するそれとの間に区別はない（min ghair farq)」，「神の 永遠性 (azaliyah) は未来も過去も包搨 (muhịțh) している」, 「神の始まりのない永遠 性（azaliyah）と終わりのない永遠性（abadiyah）とは，真の意味において異なるとこ ろはない。ただ, 前者は時間的過去との関係から“azalĩyah”という表記を以って, 後者 は時間的末来との関係から“abadiyah”という表記を以って説明されているのである。」 これらの表現は時間概念を覆すような表現を用いて神の時間的秩序に対する超越性を表 そうとしているが，いずれも無限なものを有限な言語によって表現しようとする場合の， 表現可能な限界を示す例といえるだろう。通常の言語における論理では互いに矛盾する ことがらが同一の事態として成り立っている，ということで現象階の枠組を超え出でつ つ，しかし何らかの言葉を以って表現をしてしまった以上，その表現はやはり言語の有 限性の壁にぶつからざるを得ないからだ。

すなわち，「神は時間的存在者ではない」というとき，既に「時間」概念は不可避的に 理解のプロセスに組み込まれてしまっている。「時間」のない状態を考えるためには, 否 定的ながらも時間概念を援用せざるを得ない。例えばハマダーニーは，天地が神の「能 力」により存在せられる以前には, 「以前 (qabl)」「以後 (ba‘d)」は存在しなかったと言 う。この例は，「以前」も「以後」もない即ち時間のないところへ，「以前」という時間 概念を持ち込まねば表現できないことを示している。このような表現では，言語によっ て記述すると同時に言い表わされようとしていた無限は有限な概念として凝固してしま い，無限を無限としてはその内に捉えきれない。従って，どれほど多様に表現してもし ずぎるということはなく，それどころか表現するのを止めればたちまち表現は有限の範 疇に納まってしまう。このためにハマダーニーは, 少しずつ言葉をずらしながら次々と 同様の表現を重㱛ていくように見える。

もう少し引用を続けよう。「神の永遠性は, あらゆる時と共にあり, あらゆる時の中に あるが，それにも関わらず，あらゆる時を包搨し，あらゆる存在に先行する。」このよう に神の時間に対するあり方について，様々に述語付けできるということは，人間の側か ら見れば神は時間に対して如何様にでもあり得るのであり，この事態を神の側から見れ 
ば，先に見たように神とあらゆる時間との関係は一様であるということになろう。ハマ ダーニーはこれらの表現を通じて人間の視点と神の視点とを行きつ戻りつしながら「比 喻的表現」の可能性を探ることも試みているのではないだろうか。

次に引用する表現も, 視点の転換が効果的に使われている例だと思われる。「神の存在 はあらゆる事物に対して等しく先行している。従って, 神が世界に先立って存在してい るのは, 例えば神がこの書物に書かれている言葉の存在に先立って存在しているのと何 ら変わりはない。」ここでは, 世界創造以前も以後も神の諸事物に対する超越性に変化は ないことが意味されているだろう。神と諸事物の関係を判断するために世界創造を基準 とするのは，むしろ人間側の視点である。上述のように，ハマダーニーは世界創造以前 に時間は存在しなかったとしているが，そのように主張することで却って，世界創造以 後に関しては神の先行性を時間を尺度として判断してしまうという誤解を読者側に引き 起こすことを㲘念していたのではないか。しかし，神の側からすれば時間の枠組を超越 している以上，時間が存在していようといまいとあらゆる事物に対して等しく先行して いることに変わりない。世界も時間も，人間にとってはそれらとの関係で事物を判断す る基準となるが，神がそれらに捕われることはないのである。その意味では「神が，今 もそれ以前も以後もなく存在しているという面では, 物体は全く存在していない」とも 言える。

また，神の先行性に関する上記の引用文は，神の時間に対するあり方ではなく，神と 事物の関係は時間に左右されないという形で時間概念を否定的に用いた例ともいえる。 従って，ここにいう「先行」とは時間的に先行することではない。「本性 (dhāt) 的」か つ「高貴さ (sharaf)」における「先行性 (qabliyah)」なのである。このように, 今の例 は時間的概念から時間性そのものを奪い, 性質を変換させるという表現ともなっている。 読者の既存概念に対する先入観を取り払い，そこからの解放を喚起しようとしているの だろう。こうしてハマダーニーは，言語と言う制約の中で如何に現象界の枠組に捕われ ない表現を造り出すかを追求していくのである。

以上，「比喻的表現」の方法について明らかにしてきた。最後にこの表現方法を使用し たハマダーニーの目的について確認する。

八マダーニーの目的は，理性者を耪智的領域に到達させることであった。すなわち， 理性者が䜭智的領域に至って，神的なことがらを現実のものとして体験することである。 比喻的表現による語りは，そのための手段として位置付けられる。とはいえ，比喻的表 現を用いて学んでも, 超理性域の香り程度しか嗅ぐことはできない。従って, 比喻的表 現の範疇に留まっていては意味がない。「私が述べたよりもふさわしい．真実性を帯びた 説明表現（'ibārah）は存在しないが，ㄴしかし以上のような表記の中に真の意味の類似 
物を押し込んでしまう者は大いに誤っている。」ましてやこうした表現によって神を知 悉 (ihātah) しようとしたり，神に到達（wuṣūl）したなどと思うのはもってのほかであ る。ハマダーニーは, このような「比喻的表現」の自己目的化を繰り返し戒め，あくま でも「比喻的表現」を手段として利用し，最終的にはそこから脱していくべきことを主 張している。「比喻的表現」による理解を捨て, 超理性域のことは不可視としてひたすら に信じようとする態度 (imān bi al-ghayb) に移行していかねばならないのだ。そして， 「不可視なるものの信仰（imān bi al-ghayb)」が確固たるものとなったとき，嚄智の目 ('ain al-ma'rifah) が探求者の内面に開き, 超理性域の光が差し込んでこよう。

\section{IV. おわりに}

Zubdah というテキストは, 現象界側のものである言語を援用して可能な限り本来の 内容に近づけた表現によって語られており，その言語表現を取り掛かりとして，テキス トの背後に措定された超越的世界へ到達することを読む者に要請してくるような性質を 持つ。冒頭で触れた通り，このような性質をテキテキストを読むための手掛かりの一つ と考えたいというのが本稿の立場である。

著者の手を離れたテキストは，その扱いを読み手に委ねることとなる。読み手側の立 場から読まれることは原理上必然となり，純粋に我々の持つ論理によって解釈すること もできる。しかし，そのときテキストは元の文脈から切り離されて，思想の生きたメッ セージは失われてしまうだろう。

また，追体験的な理解も一つの読み方だが，テキストの要請に無意識の内に従い，テ キストの内部に取り込まれることになる。この場合，体験の同一性を証明することは原 理的にできないし，テキストの内容は読み手にとっても表現不可能なものとなるという 問題が生じる。

対象が神秘主義のテキストである以上，最終的にはテキストの外に措定された真理へ の到達を目指すのが，テキストに対する誠意ある態度だろう。逆説的なようだが，その 目的のためにも読み手は自分自身の立場を保っていなければならない。時間，空間を隔 て，言語的な制約をも受けているテキストに，直接飛び込むのは乱暴であろう。たとえ テキストの外部にあるはずの真理は唯一であるとしても，テキストの記述自体は思想家 の負う時代的，地理的，文化的等諸々の背景に不可避的に規定されており，読み手もま た，異なる諸背景を負っているからだ。そのことを認識した上でテキストと相対するこ とが，テキストに対し敬意を払うことに通じよう。

自身の立場からテキストの示唆する真理へ向かうとき, 恐らく「語り方」は重要になっ てくる。真理を目指すには，まずテキストを通っていかなければならない。その際，内 
容を抽出するだけでなく，「語り得ないこと」の「語り方」を意識的に捉えることは，テ キストを与えられた材料として最大限に生かすことへと繫がるはずである。そして，そ の営みは教義内容を読み手側の論理で一方的に分析してテキストの生きた文脈を殺すこ となく, 追体験的な理解によってテキストの内部に入り込むこともなく，過去のものと してのテキストとの距離を保ちつつ，テキストの残した痕跡を辿り直すための一助とな るのではないだろうか。

注

（1）本稿では文字として残されたテキストの類いを念頭に置き，「語る」を「書く」「記 述する」などと同義で用いる。「語る」という表現を用いるのは，神秘主義のテキスト に広く見受けられるメッセージ性を考慮に入れるためである。

（2）このような問題意識を設定するに当たって，鶴岡賀雄氏の研究から示唆を受ける ところが多かった。鶴岡賀雄「宗教学者は神秘家のテクストにいかに接近するか」脇 本平也・柳川啓一編『現代宗教学 2』東京大学出版会, 1992，87-113. 同「なぜ言語 が宗教思想研究の問題となるのか」島薗進・鶴岡賀雄共編『宗教と言葉一宗教思想研 究の新しい地平一』大明堂，1993，1-11. 同『十字架のヨ八ネ研究』創文社, 2000, 4557.

(3) 以上の略歴についてはテキストによる。Zubdat al-Haqā'iq, ed. 'Afīf 'Usayrān, Tehran, 1961, 6:3-7 : 13. (以下, 原典からの引用は, ページと行の間にコロンを打っ て示す。)

Zubdah の評価については, 以下の論文を参照した。T. Izutsu,“Creation and The Timeless Order of Things: A Study in the Mystical Philosophy of 'Ayn al-Qudạt," Philosophical Forum 4 (1972), 124-140; H. Landolt, "Two Types of Mystical Thoughts in Muslim Iran: An Essay on Suhrawardī Shaykh al-Ishrāq and 'Aynul Quzāt-i Hamadānī," Muslim World 68 (1978), 187-204.

「哲学的」とは，理性を超えた次元を問題とするに当たり，哲学・神学など理性の 範疇にある学問を援用するという意味においてである。(Zubdah 11：9-17.) しかし厳 密に言えば，理性の彼方を主眼とする時点で哲学そのものではなく，神秘主義のテキ ストとみなすのが妥当だろう。ダバシは, ハマダーニーが哲学・神学のみならず神秘 主義をも超えていくとするが，ここでは，既存の知の枠組からはみ出ていくような性 質そのものを広く「神秘主義的」と捉えておく。名バシのいうのは，形式化していた こともあり得る当時の神秘主義の姿であろう。H. Dabashi, Truth and Narrative: The Untimely Thoughts of 'Ayn al-Qudāt al-Hamadhānī, Richmond, 1999, 301-302, 325327, 590-595, etc.

(4) Tamhīdāt に対する評価については, 以下の論文による。P.J. Awn, Satan's Tragedy and Redemption: Iblīs in Sufi Psychology, Leiden, 1983, 134-150; C. W. Ernst, 
Words of Ecstasy in Sufism, New York, 1984, 73-84; L. Lewisohn, "In Quest of Annihilation: Imaginalization and Mystical Death in the Tamhīāt of "Ayn alQựāt Hamadhān̄ī, in L. Lewisohn (ed.), Classical Persian Sufism: From Its Origin to Rumi, London, 1993, 285-336.

(5) A. J. Arberry (trans.), A Sufi Martyr: The Apologia of 'Ain al-Qudāt alHamadhānī, London, 1969, 9-14.

（6）ハマダーニーの「語り方」を意識した研究は, ダバシの前掲書に見られる。語り 掛け口調, 一人称の多用, 挑発的な物言いなどを対象とし, ハマダーニーの自我意識 の強さ, 反権力的志向などを導き出すが, 内容把握へと議論がつながっていかない。 本稿は, 飽くまで内容を読み解くために「語り方」を考察するという立場をとる。 H. Dabashi, op. cit...,364-442, etc. もちろん, ダバシの挙げているような特徵も論点に含 めるべきであるが，本稿では分析対象を「比喻的表現」に限定して議論の焦点を絞る。

（7）“tashbīh”, “mithāl”, “tamthīl” などの術語も同様に用いられている。訳語につい ては本稿IIIの冒頭にて後述するが, 「似たものを以って説明する」という広い意味で「比 喻的」と訳す。より正確には, 本来的な意味を直接には表現できないが, 可能な限り 真の内容に近づけて表現しようとする方法と考えられる。「近似的」などと訳した方が ニュアンスは近いかもしれないが，より一般的に訳しておく。

(8) Zubdah 4:6-7.

(9) Zubdah 4:7-8.

(10）Zubdah は，全体がプロローグ，100の短い節及びェピローグからなっている。

(11) Zubdah 4: 8-9.

(12) Zubdah 4: 9-10.

(13）Zubdah 4: 10-11. テキストの該当箇所を直訳すると「表記という型にはめこまれ た真の意味内容は伝わらない」となるが, 真の意味内容が伝わらないのは表記という 型に入った状態にあるためだと考えられるので本文のように訳出する。

(14) Zubdah 13: 6 .

(15) Zubdah 23: 12, 27: 17, 31: 1 etc.

（16）唁智者（‘ārif）に固有の場は超理性域であるとされる。Zubdah 23: 15. Zubdahで は, 存在論的領野が理性的な思考の次元と超理性的な跈智の属する次元とに大きく二 分されており，㕡智の対象は「神的な知識 (ex. 'ulūm ladnīyah)」となっている。cf. Zubdah 67: 16, 68: 10 .

(17）Zubdah 30: 12-13. 思弁的な知は，同じ文脈で理性と同次元に置かれている。

(18) Zubdah 30: 8-11. cf. Zubdah 84: 13-15.

（19）内容が異なるだけでなく，神的領域への「親しみ」が増すにつれて，現象界に対す る「親しみ」は弱まっていくとされ，両者は相反する関係にある。(Zubdah 30: 11-12.) (20)Zubdah 30: 12-15. 両者の意味するところが異なるといっても，同じ表記を適用す る以上，何らかの共通する性質があると考えるべきだろう。“uns”の例でいえば，ある 
事物に対して, できる限り近しくあろうとする性向という点は共通しており，その対 象及び追求の仕方が異なるということであろう。すなわち，神的領域では神の顕現を 近しく体験（dhawq, mushāhadah）することを，現象界においては対象を知識として 把握しようとする作用を指すと思われる。なお, 神的領域に対して思弁的な知への「親 しみ」を適用してしまうとき, 理性の領域にある者は「神の存在」を知識の対象 $(\mathrm{ma}(\mathrm{lm})$ として認識し, 理性的に捉えようとしているのである。(Zubdah 29: 13-30:

6.) 本稿注73を参照。

(21) Zubdah 52: 5-53: 1.

(22) Zubdah 52:2.

（23）このような表現には，言語では汲み尽くせない神的領域の内実の豊穣さが含意さ れていよう。以下の論文も参照のこと。井筒俊彦 (黒田寿郎訳)「アイヌ ト・ハマダーニーの思想における神秘主義と言語の多義的用法の問題」『オリエント』

14-2 (1972), 148-150. 同「スーフィズムと言語哲学」『思想』6（1984）, 16.（それぞれ 論文 1 , 論文 2 とする。)

(24）Zubdah 10: 14-11: 6. Zubdah は全編にわたって理性への警句に満ちており，理性 者に対して語るという著者の意識が鮮明に表されている。またハマダーニーは, 㕡智 領域に到達できるのは理性者の内, ごく一部であると見ている。それでもハマダーニー は彼らへの語りかけを諦めず，わずかな可能性にかけようとしていると思われる。

(25) Zubdah 32: 8-10.

(26)「私がこれらの諸節で述べてきたことの内容は, 直観的に目撃せられること (mushāhadah bi-al-dhawq) なのだ。…ただ，これらの内容を説明するには言語的表現 によらざるを得ないのである。神を直観的に知った者は, 彼が直に味わって理解した 当の内容の真実を伝える表現を見出せないのは全く疑いのないことである。」(Zubdah 65: 16-19.)

(27) Zubdah 4: 13-14.

(28) 本稿注 7 を参照。

（29）しばしば,「比喻的表現」という表記では真実は理解できないことが表明されてい る。cf. Zubdah 4: 14-15, 68: 10, 68: 18. また，手掛かりとするといっても，「比喻的表 現」を手段とするだけでは真実を理解できるようにはならない。後段で見るように， 最終的には神的領域をただ盲目的に信じるという状態を経なければ到達不可能なので ある。例えば「不可視 (ghayb)を「比喻的表現」なしに (min ghayr tashbih wa tamthìl) 信じる程に…熟考せよ」と言われている。(Zubdah 91: 18-92: 1) 本稿注66, 69, 75 も 参照のこと。

(30) Zubdah 77: 6-10.

（31）「垂直的多義性」とは井筒の用いる訳語である。同次元で複数の意味を持つという, 通常の意味での言葉の多義性に対比させた表現である。井筒俊彦 前掲論文 1,150 154；同 前掲論文 2，15-18. 本文で述べたように，「多義性」と訳せる用例は限られ 
ると考えるため，本稿では用いない。

(32) “tashābuh”, “mutashābih” の他, “tashbīh”, “tamthīl”などの術語も互換性があ り, 特に「比喻的」と「多義的」との違いに対応した使い分けは見られない。もとよ りハマダーニー自身の関心は, “tashābuh”などが現象界の範疇にあるため, 理性者が 誤解をしやすいという点にあろう。

（33）同一の主体が複数の次元にわたる能力を同時に持つという状況は想定されていな いようである。本稿注29でも述べたように，「比喻的表現」を媒介にしただけでは呫智 領域への到達は不可能なため，少なくとも理性者がZubdah を読んでいる段階である 表記の有する多義を同時に理解することはできない。跈智者についても，理性的な知 識を知悉していなくても閣題はないとされており, 必ずしも下位次元の知識まで包括 的に理解しているとは限らない。(Zubdah 35: 5-6.)

(34）Zubdah 21: 19-22: 2. “majāz” には, 真なるものに対する事物の仮象性を示すニュ アンスがあると思われる。例えば，「神的主体 (huwiyah al-haqīiiyah)」に対する人間 の主体は “huwīyah al-majāzĩyah”と言われている。(Zubdah 85: 9)

(35) Zubdah 22:2-3.

(36) Zubdah 22:9-14. イブン・スイーナーの「神は個物を知らない」という命題が議論 の背景にあるだろう。cf. O. Leaman, An Introduction to Medieval Islamic Philosophy, Cambridge, 1985, 112-120.

(37) Zubdah 24: 12-18.

(38) Zubdah 52:7-8.

(39) Zubdah 52: 9-12.

(40) Zubdah 52: 9-10.

（41） ハマダーニーが念頭に置くのは，イブン・スィーナーの「原因は結果を必然化させ るため, 原因と結果は同時存在する。という主張だろう。八マダーニーは「条件」を 導入することで, 原因に対する結果の時間的遅延を容認するが, 後述のように,「条件」 の存在論的位置付けや神という原因の完全性との矛盾など問題は残る。cf. Zubdah 44: 12-13. M. E. Marmura, "Avicenna on Causal Priority," Islamic Philosophy and Mysticim, New York, 1981, 67-72. ガザーリー（兄）も同様の場面で「条件」の概念を 扱っている。cf. R. M. Frank, Creation and The Cosmic System: Al-Ghazālī \& Avicenna, Heidelberg, 1992, 22-31, 55-56.

(42) Zubdah 52: 15-18.

（43）これもまた, 神の「能力」を太陽, 条件を雲, 事物を地上によって喻える「比喻的 表現」の例となっている。Zubdah 52: 15-53-1.

(44) Zubdah 47: 8-11.

（45） ハマダーニーは, 神の直接的創造を主張するためにも「条件」概念を導入したと思 われる。(イブン・スィーナーの)「一からは一しか生まれない」という命題に反駁し, 存在の原因として神のみを認めようとしているからである。cf. Zubdah 62: 17-64: 10. 
M. E. Marmura, “Avicenna IV. Metaphysics,” Encyclopaedia Iranica Vol. 3, 1989, $77-78$.

（46）Zubdah 25: 7-9.この記述の意味する正確なところはわからない。「永遠なる能力」 は事物を「非存在 (ma'dūm)」から存在へともたらすのだが, 「非存在」とは「(存在) 不可能なもの (muhāāl)」ではなく，いわば「未だ存在していないもの (alladhī lam yūjad）である。従って, 「非存在」は端的な無ではなく, 現象界に存在する以前の事 物の状態と考えられる。“lā min shay””には，既に存在している物からではなくでも 創造できるという含意があるのではないだろうか。人間と違う，というのは，人間の 場合既存のものからしか何かを造り出すことができないことを意味し得るだろう。cf. Zubdah 24: 4, 45: 6, 53: 4-11.

但し，ハマダーニーが存在レベルの創造の前段階としての原初的な創造を想定して いたかどうかははっきりしないため, 非存在自体の源泉をどこに求めるべきか明確で はない。cf. R. M. Frank, op. cit. 62-65.

(47）Zubdah 44:7-9, 52:8-9. ハマダーニーは，原因の議論にも異なる認識能力を持つ 主体という視点を導入し，現象界における仮の因果関係と神の直接的創造とを両立さ せようとしているように思われる。なおがザーリーも，イブン・スィーナー的な宇宙 を支配する必然的因果関係の存在とアシュアリー神学における神の直接創造説とを調 和させるため苦心していたようである。cf. R. M. Frank, op. cit. 22-37.

(48) Zubdah 48: 1 .

(49) Zubdah 49: 8-10.

(50) “kull shay’ hālik illā wajh-hu” (コーラン28章88節) コーランの訳は,『日亜対訳・ 注解 聖クルアーン』日本ムスリス協会，1996年による。

(51) Zubdah 51:7-9.

(52) Zubdah 51: 10-12.

（53）神的領域での構造に生かされているのは, 外在物とその像だけである。鏡, 関係, 見る主体が神的領域において何に相当するのかについて言及はなく，存在論的な位置 付けに曖昧さが残る。但し，諸事物の直接の原因は神であるから，神以外の要素は構 造上, 先の「条件」と同等の位置にあるとみなせよう。

(54) Zubdah 48: 1-3.

(55）Zubdah49: 10-12.「関係が無になる」事態が具体的にどのような状態を指すのかは 不明だが，諸事象間の因果関係は必然的・普遍的ではなく，変化の可能性に対して開 かれた偶然的なものとみなす立場が背景にあろう。ハマダーニーは一瞬ごとの創造の 更新という見解を嚄智者のものとしている。神と事物間の関係が同じ状態で続いてい ると，事物は一見同一のままに見えるが，一瞬ごとに固有の関係が結ばれているのが 真実なのである。(Zubdah 60: 8-61: 10.)

(56) Zubdah 49: 15-18. 外在物と映像は時間的には同時に存在するが, 映像は外在物が あってはじめて存在できる。位階的な先行とは, そのような, 結果に対する原因の原 
理的な先行の意味に近いと考えられる。

（57）このような表現は, 言語の構造を変容させることによって, 通常の言語の記述形態 では表現不可能な無限なものを表現しようとするものと考えられる。cf. M. Sells, "Ibn 'Arabi's Polished Mirror: Perspective Shift and Meaning Event," Stvia Islamica 67/68 (1988), 128-134.

(58) Zubdah 23: 18-24: 1 .

(59) Zubdah 57: 1.

(60) Zubdah 59:2.

(61) Zubdah 59: 12-15.

(62) cf. M. Sells, op. cit., 130.

(63）Zubdah 54: 15-17. 背景には世界の始原に関する論争がある。ハマダーニーは，世 界の無始性も時間軸上の一点における創造も否定し，世界の存在以前には神は時間を 創造していなかった，すなわち時間は存在していなかったと主張するのである。cf. Zubdah 54: 14-55: 19. M. E. Marmura, "Avicenna and The Kalām,” Zeitschrift für Geschichte Dẹr Arabisch-Islamischen Wissenschaften 7 (1991/92), 172-183.

(64) Zubdah 59: 10-15.

（65） セルズは，神に視点を置くことによって，神に関する表現は言語的記述の域を脱 し，神からの開示の言葉へと移行していくと見ている。M. Sells, op. cit., 131-134.

（66）Zubdah 56:14-16. なお，引用文は「両者（の先行性）を区別している者は，未だ 「比喻的表現（tashbīh）」の次元という狭き道に留まっている。と続く。相互矛盾す る表現について両者が同一の事態を示しているという見方ができれば，現象界の枠組 を超え得るが，区別をしてしまうならそれらの表現を通常の言語の範囲内で判断して いることになる。後者の状態にある者が「比喻的表現」の次元にあるとすれば，やは り「比喻的表現」自体はあくまで現象界の範疇に属するといえる。本稿III冒頭の議論 及び注29,69を参照のこと。また, Zubdah 58:9-13の記述も同様の趣旨となっている。 (67）Zubdah 56: 11-12. 物体 (jism) は世界を構成する要素とみなされている。cf. Zubdah 54: 16-55: 2 .

（68）「必然的存在者(神)の…諸事物に対する, 高貴さと本性上の先行性は無限である。」 (Zubdah 75: 11-14.) このような「先行性」の性質について特に説明はないが，神が 存在物の原因であり創造主である以上，神が存在しなければ存在物は存在できない。 そのような, 神が存在物に対して必然的・原理的に先行しているという事態を指すの だと思われる。本稿注56を参照。

（69）「このような一般的な比喻を, あなたの非力な理性と虚栄に満ちた知の脆弱さに応 じた形で理解することだ。努力すれば，あなたの弱い理解力でもこの「比喻的表現 (mithāl)」から何かしら得るところがあるだろう。とはいえ，「比喻的表現 (tashbīh)」 には気をつけよ。」(Zubdah 57: 15-17.) 本稿注29，66も参照のこと。

（70）「意図された真の意味を理解するには，硁智の眼 ('ayn al-ma'rifah) の開くのを待 
たねばならないが，“非力な者（理性者）でも，恐らくその香りをわずかに嗅ぐこと はできるだろう。」(Zubdah 57:6-7,9.)

(71）“ibārah”はしばしば“lafz”と並記され「表記」の意味で用いられる術語である。

(72) Zubdah 58: 7-9.

（73）「神は理性よりも高く（fawq）あられせられ，理性を包捸（muhīt) されている。 しかるに, 理性が神やその属性を包摂することなどどうしてできようか。」(Zubdah 25: 13-14.) 本稿注20を参照。

（74）「探求者が知の道（tarīq al-'ilm）を通って神的な永遠性に到達しようとするのは, 明らかに不可能なことである。」(Zubdah 60: 3.)

（75）「不可視なるものの信仰 (immān bi al-ghayb)」とは, 理性の次元から叡智的次元に 移行する間の中間的な状態を示す。硁智界のことは理性では直接認識できないので, 「そのことを確実であると信じ込むとき，その認識（i'tirāf）は不可視界を信じること となる。」(Zubdah 89: 7-8.) そのような信じ方は, 比喻的な理解に拠らず (min ghair tashbīh wa tamthīl), かの地に到達するまで必要となる (Zubdah 89: 11, 91: 18-92: 1.)。

（76）「(不可視界を）信じること（taṣdīq）があなたの本性（țab'）となったとき‥あな たの内面はまさに準備万端となり，そこへ神からの光が流れ込んでくる…それは理性 の彼方に現れる領域の一つの徵（athar）なのである。(Zubdah 92: 8-14.)

（77）「語り方」は様々な面から複合的に捉え得る。本稿の考察は，著者の明確な意見表 明とそれに基づく実例のみを対象としたに過ぎない。

（78）テキスト内部の文脈も，時代や場所といった外的な文脈も含めてのことである。 